\title{
A null c-myc mutation causes lethality before 10.5 days of gestation in homozygotes and reduced fertility in heterozygous female mice
}

\author{
Ann C. Davis, ${ }^{1}$ Marie Wims, ${ }^{1}$ Gerald D. Spotts, ${ }^{2}$ Stephen R. Hann, ${ }^{2}$ and Allan Bradley ${ }^{1}$ \\ ${ }^{1}$ Institute for Molecular Genetics, Baylor College of Medicine, Houston, Texas 77030 USA; ${ }^{2}$ Department of Cell Biology, \\ Vanderbilt University, School of Medicine, Nashville, Tennessee 37232-2175 USA
}

\begin{abstract}
To directly assess c-myc function in cellular proliferation, differentiation, and embryogenesis, we have used homologous recombination in embryonic stem cells to generate both heterozygous and homozygous c-myc mutant ES cell lines. The mutation is a null allele at the protein level. Mouse chimeras from seven heterozygous cell lines transmitted the mutant allele to their offspring. The analysis of embryos from two clones has shown that the mutation is lethal in homozygotes between 9.5 and 10.5 days of gestation. The embryos are generally smaller and retarded in development compared with their littermates. Pathologic abnormalities include the heart, pericardium, neural tube, and delay or failure in turning of the embryo. Heterozygous females have reduced fertility owing to embryonic resorption before 9.5 days of gestation in $14 \%$ of implanted embryos. c-Myc protein is necessary for embryonic survival beyond 10.5 days of gestation; however, it appears to be dispensable for cell division both in ES cell lines and in the the embryo before that time.
\end{abstract}

[Key Words: c-myc; gene targeting; null mutation, embryonic lethal]

Received November 25, 1992; revised version accepted January 25, 1993.

c-myc was first identified as the transforming element in the avian retrovirus MC29, which induces myelocytomatosis and tumors of the hemopoietic lineages in chickens (for review, see Enrietto 1987). Investigation of the mechanism by which c-myc exerts its oncogenic action and, indeed, the normal cellular function of the proto-oncogene, has been approached from many perspectives. No clear answer has emerged as yet ffor reviews, see Cole 1986; Lüscher and Eisenman 1990; Spen. cer and Groudine 1991; Prendergast and Ziff 1992).

Deregulated c-myc expression contributes to, but is not necessarily sufficient for, oncogenic transformation. c-myc mRNA levels in plasmacytomas are similar to the levels seen in mitogen-stimulated primary B cells (Keath et al. 1977). c-myc overexpression in rat embryo fibroblasts does not result in tumorigenicity, but cotransfection of c-myc with the EJ-ras gene does (Land et al. 1983; Lee et al. 1985). In transgenic mice, overexpression of c-myc under the control of the immunoglobulin enhancer results in a high incidence of pre-B- and B-cell malignancies (Adams et al. 1985; Langdon et al. 1986 ). The tumors are clonal, although the majority of $B$ cells have a disregulated myc gene. Moloney murine leukemia virus (Mo-MLV) infection of $\mathrm{E} \mu-$ myc transgenic mice results in a dramatic acceleration of pre-B-cell lymphomagenesis and has identified, by proviral tagging, other genes that cooperate with c-myc to induce B-cell tumorigenesis (Haupt et al. 1991; van Lohuizen et al. 19911 .

The relationship between c-myc expression and cell growth has been demonstrated in tissue culture cells stimulated to divide by growth factors. c-myc is one of the immediate early genes associated with stimulation of BALB/c-3T3 fibroblasts by platelet-derived growth factor (PDGF) in culture. c-myc mRNA levels are elevated 40-fold, 1-3 hr after the addition of PDGF, and there is a direct correlation between the mitogenicity of various PDGF concentrations and the amount of $c-m y c$ mRNA (Kelly et al. 1983). Other growth factors that have been shown to induce c-myc expression include interleukin-7 (IL-7) in pre-B cells (Morrow et al. 1992), IL-4 in B cells (Klemsz et al. 1989), epidermal growth factor (EGF) in Madin-Darby canine kidney cells (Hauguel-DeMouzon et al. 1992), and CSF-1 in NIH-3T3 cells expressing a CSF-1 receptor (Roussel et al. 1991).

In the mouse embryo, c-myc is widely expressed, and expression correlates generally with rapid cellular proliferation. At 6.5 days of gestation, c-myc is expressed at high levels throughout the embryonic tissue and in the maternal deciduum. By 7.5 days, myc levels are highest in the extraembryonic tissue of the ectoplacental cone, the extraembryonic ectoderm, and the allantois. All 
other tissues of the 7.5-day embryo express lower and roughly equivalent levels of $\mathrm{c}-\mathrm{myc}$, including the highly proliferative zone of the primitive ectoderm. By 8.5 days, extraembryonic expression has decreased and low uniform levels of expression remain throughout the embryo (Downs et al. 1989).

The relationship between cell division and terminal differentiation in development is generally considered to be reciprocal. Cell lines [including HL60, F9 embryonal carcinoma cells, and myeloid erythroleukemia (MEL) cells], which can be induced to differentiate in culture, cease to divide, and this is accompanied by a decrease in c-myc mRNA and protein levels (Bentley and Groudine 1986; Spotts and Hann 1990; Whitman et al. 1990). Exogenous high levels of c-myc expression in MEL cells leads to continued cell proliferation and prevents differentiation into mature erythroid cells (Dmitrovsky et al. 1986; Coppola et al. 1989). The hypothesis that increased c-myc expression favors cell division at the expense of differentiation is also suggested by a Emu-myc transgenic strain, where the pre-B cell population is expanded with a simultaneous reduction in mature B cells (Langdon et al. 1986). The corollary that decreased c-myc expression results in decreased cell growth and thus allows differentiation is supported by experiments using antisense mRNA in HL60 cells and F9 embryonal carcinoma cells (Griep and Westphal 1988; Holt et al. 1988; Prochownik et al. 1988; Wickstrom et al. 1988).

c-myc is one of a family of cellular genes with similar protein structure, including $\mathrm{N}-m y c$ and L-myc (for review, see Depinho et al. 1991). All are associated with malignancy when deregulated, heterodimerize with Max (Blackwood and Eisenman 1991), and cotransform rat embryo fibroblasts with EJ-ras (Depinho et al. 1987). They differ in their expression patterns both in the developing embryo (Downs et al. 1989; Stanton et al. 1992) and in cell culture systems (Sejersen et al. 1986, 1987). Several putative cellular targets of the c-myc transcription factor have been reported including plasminogen activator inhibitor 1 (Prendergast et al. 1990), hsp 70 (Taira et al. 1992), and $\alpha$-prothymosin (Eilers et al. 1991), although the relevance of these genes to the biological effect of myc expression is as yet unclear.

To directly assess the role of c-myc function in cellular proliferation, differentiation, and embryogenesis, we have used homologous recombination in embryonic stem $(E S \mid$ cells to generate both heterozygous and homozygous c-myc mutant ES cell lines. The ES cell lines proliferate in culture and were used to demonstrate that the mutation is a null allele at the protein level. Mouse chimeras from heterozygous cell lines transmitted the mutant allele to their offspring, and the mutation is lethal in homozygotes between 9.5 and 10.5 days postconception (dpc). Female heterozygotes have reduced fertility owing to embryonic resorption before $9.5 \mathrm{dpc}$.

\section{Results}

Gene targeting of c-myc in ES cells

c-myc was mutated in $\mathrm{AB} 1 \mathrm{ES}$ cells using a replacement vector strategy with positive-negative selection (Mansour et al. 1988). The targeting construct (Fig. 1) contains $10.6 \mathrm{~kb}$ of the mouse $\mathrm{c}-m y c$ gene, including coding exons 2 and 3 . The positive selectable marker is a neo expression cassette, with an RNA polymerase II promotor and an efficient polyadenylation sequence, inserted into the second exon, $150 \mathrm{bp}$ downstream of the AUG translation initiation codon for the c-Myc 2 protein (Hann et al. 1988). This particular neo gene has been shown to be efficiently expressed in ES cells (Soriano et al. 1991). A herpes simplex virus (HSV) thymidine kinase gene $(t k)$ is placed at the 5' end of the region of homology such that a homologous recombination event would result in incorporation of the targeting vector and loss of the $t k$ gene. Selection in G418 for integration of the targeting vector, and in FIAU (a toxic thymidine analog incorporated in HSV-tk-containing cells) for the lack of a $t k$, enriches for targeted events.

The targeting vector was linearized, electroporated into ES cells, and grown either under G418 selection or G418 and FIAU selection for 10 days. The frequency of

\section{A. Homologous Recombination}

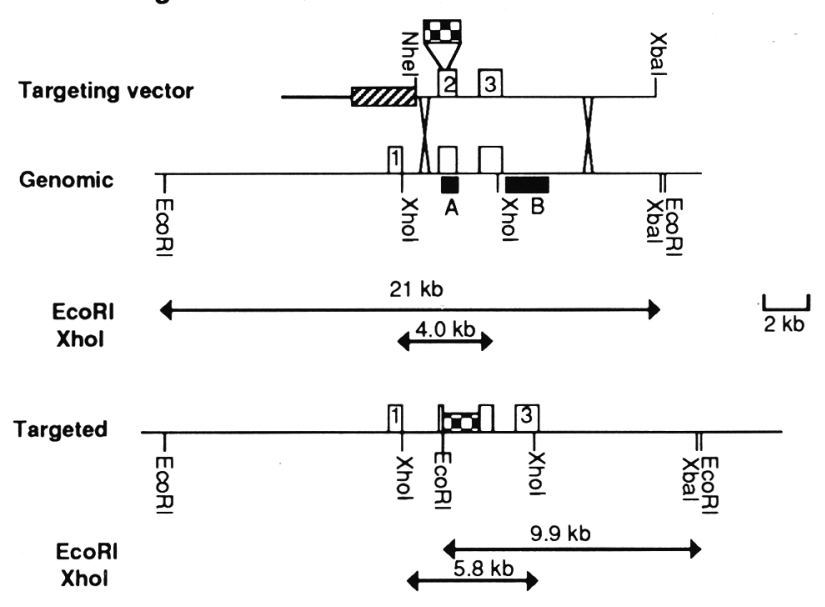

B Diagnostic PCR

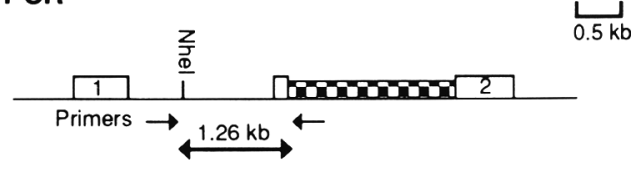

Figure 1. Targeting vectors, PCR strategy, and recombination at the c-myc locus. $|A|$ Restriction map of the c-myc locus before and after targeting. The thin lines represent $\mathrm{c}-m y c$ genomic sequences, with the exons shown as open boxes, neo as a checkerboard box, and TK as a hatched box. The plasmid sequences are shown as a thick line. The diagnostic EcoRI and XhoI fragments for homologous recombination are shown below the wild-type and targeted loci. The probes used for Southern analysis are shown as solid boxes-probe A in exon 2 and probe $B$ in exon 3. $(B)$ The scheme for identification of targeted loci by PCR. c-myc genomic sequences are shown with neo (checkerboard) inserted in exon 2 . The primers are shown as singleended arrows, and the diagnostic fragment as a double-ended arrow. 
G418 resistance was $2.6 \times 10^{-4}$, whereas the G418 and FIAU resistance was $0.76 \times 10^{-4}$. Individual colonies were picked and screened by polymerase chain reaction (PCR) in pools of six. The PCR strategy is shown in Figure $1 B$. Of 40 pools tested, 22 were positive, giving a minimum targeting frequency of 1 in 11 G418- and FIAU-resistant clones. For the six most strongly positive pools, clones were tested individually by PCR, and 13 clones of 36 tested were positive. Twelve PCR-positive clones were chosen for extensive Southern analysis, and nine of those clones proved to be correctly targeted. The strategy for the Southern analysis is shown in Figure 1A, and the results for the two clones that were introduced into the germ line are shown in Figure 2. It should be noted that both ends of the recombination event were checked for fidelity.

\section{The c-myc mutation is a null allele}

We anticipated that the neo insertion in the second exon of $c-m y c$ would generate a null allele. The insertion interrupts the coding sequence $195 \mathrm{bp}$ downstream of the CUG translation initiation codon for the $\mathrm{c}-\mathrm{Myc} 1$ protein and $150 \mathrm{bp}$ from the AUG start codon for the c-Myc 2 protein. However, an in-frame AUG with an efficient Kozak consensus sequence for translation initiation is located 63 codons downstream of the insertion (Bernard et al. 1983; Kozak 1986). Should this region be transcribed, it is theoretically possible that translation might initiate at this downstream codon, thus producing a short form of c-Myc. We elected to create a homozygous c-myc mutant cell line to determine whether the mutation is a null allele, as c-myc is normally expressed in dividing ES cells.

Our strategy was to target each allele separately in culture as has already been demonstrated for pim-1/Te Riele et al. 1990\}. The targeting strategy requires a pos-

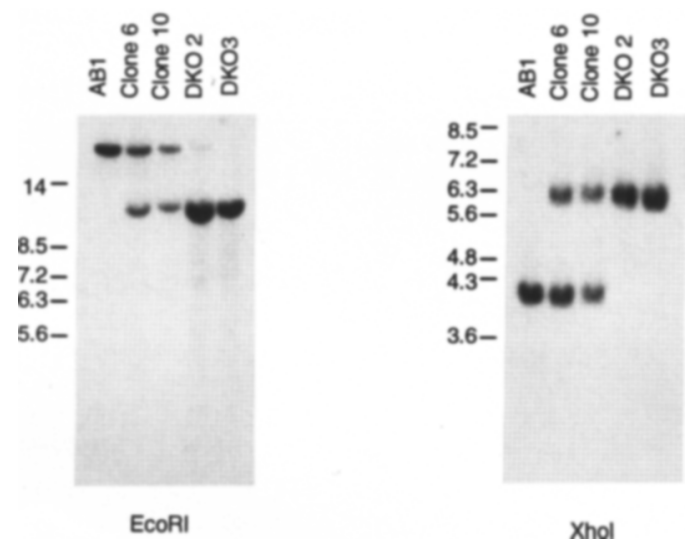

Figure 2. Southern analysis of targeted clones. Five cell lines are shown, including wild-type ES cells $(A B 1)$, the two myc clones targeted with the neo-containing vector, clones 6 and 10 , and two cell lines in which both alleles have been targeted DKO2 and DKO3 (see text). (Left) An EcoRI restriction digest hybridized with probe $\mathrm{B}_{i}$ (right) an XhoI digest hybridized with probe A (Fig. 1). itive selection marker to be incorporated into the c-myc locus. If both alleles are to be targeted by two rounds of electroporation, then two different positive selectable markers are required. We chose to use the bacterial $g p t$ gene in hypoxanthine phosphoribosyl transferase (hprt)negative ES cells as the second selection scheme. In previous work hprt-negative mice (Kuehn et al. 1987) were produced by random retroviral insertion. ES cell lines generated from these mice were hprt negative [sensitive to 6-thio-guanine (6-TG)] and G418 sensitive. One of the male cell lines (AB2.1) was found to generate chimeras efficiently (Soriano et al. 1991) and was used in subsequent experiments.

The targeting strategy to mutate both alleles is identical to that outlined in Figure 1. A second targeting vector with a gpt expression cassette in place of the neo cassette was constructed. Electroporation of this gptmyc vector and selection in hypoxanthine immunopterin and thymidine [HAT) gave fivefold lower total colony numbers than the neo-myc targeting construct but with a similar enrichment in FIAU. The gpt-myc targeting vector was linearized and electroporated into AB2.1 ES cells, selected in HAT and FIAU, and 79 colonies screened by Southern analysis. Of those 79 colonies, 8 were correctly targeted giving a frequency of $\sim 1$ in 10 , similar to the neo-myc targeting frequency of 1 in 11 . One of the HAT-resistant cell lines (AD52-1) was used for a second round of targeting. The AD52-1 cell line was electroporated with the neo-myc targeting vector (Fig. 1); selected in G418, HAT, and FIAU, and 22 clones, of 420 screened by Southern analysis, showed targeting of the second allele. The Southern analysis of two of the clones is shown in Figure 2, confirming that both alleles are targeted. The homozygous c-myc mutant ES cells (DKO2 and DKO3) are capable of extensive proliferation and have been grown for 20 passages with no alterations in their growth characteristics. These cells were expanded to provide material for c-Myc protein analysis.

ES cell are normally grown on feeder layers of mitomycin-inactivated STO fibroblasts. As shown in Figure 3B, these feeders synthesize significant amounts of the c-Myc proteins, so all cell lines were passaged six times on gelatin to remove the contaminating feeders. Growing cells at $\sim 50 \%$ confluence were biosynthetically labeled with $\left[{ }^{35} \mathrm{~S} \mid\right.$ methionine for $20 \mathrm{~min}$, and the c-Myc proteins were immunoprecipitated with an affinity-purified polyclonal rabbit antiserum generated against a synthetic peptide of the 12 carboxy-terminal amino acids of mouse c-myc (Spotts and Hann 1990). As shown in Figure $3 \mathrm{~A}$, several c-Myc proteins are synthesized in $\mathrm{AB} 2.1$ cells, which migrate at $65 \mathrm{kD}$ (c-Myc 2), $67 \mathrm{kD}$, and $68 \mathrm{kD}$ (c-Myc 1 ) on SDS-PAGE. Immunoprecipitation of these three proteins is specifically inhibited by the addition of the immunizing peptide. As shown in Figure 3B, high levels of $c-M y c$ protein were present in AB2.1 (grown without feeders) but absent in the cells in which both alleles have been targeted (DKO2 and DKO3). Thus, by radioimmunoprecipitation, the mutation created by these targeting vectors appears to be a null allele in ES cells. 
Davis et al.

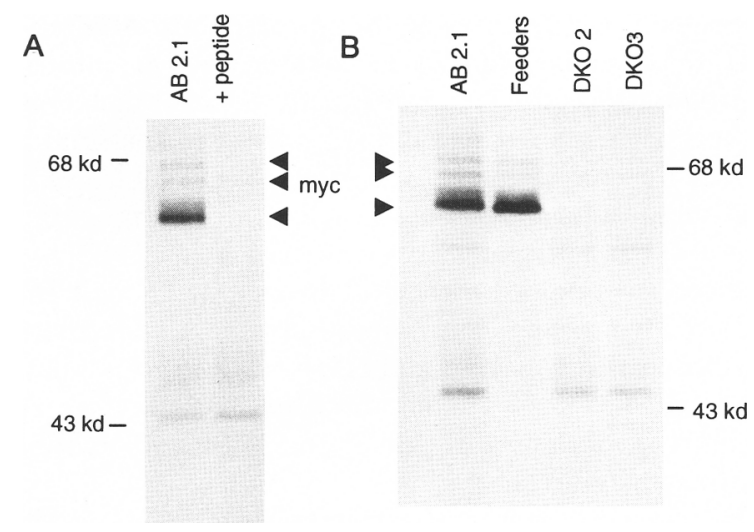

Figure 3. Radioimmunoprecipitation of c-myc homozygous cell lines. Cells were biosynthetically radiolabeled and lysed, and total TCA-precipitable counts were measured. c-myc was immunoprecipitated with an affinity-purified polyclonal rabbit anti-peptide antiserum to a peptide of the carboxy-terminal 12 amino acids of the mouse Myc protein. The proteins were separated by SDS-PAGE, and an autoradiograph was taken. For the ES cell lines, $35 \times 10^{6}$ TCA-precipitable cpm was used, and for the feeders, $15 \times 10^{6} \mathrm{cpm}$ was used. Molecular markers are indicated. $(A)$ Demonstration that $c-m y c$ is present in wild-type ES cell lines (AB2.1) as 65-, 67-, and 68-kD bands and that these bands are specific for the immunizing peptide. (B) C-Myc protein is absent in the homozygous c-myc mutant cell lines (DKO2 and $\mathrm{DKO} 31$ and present in AB2.1 and feeders.

\section{Generation of mice with the c-myc mutant allele}

The ES cell lines targeted with the neo vector in one allele were used to introduce the mutation into the germ line. Of the 9 targeted clones identified, 7 were injected into $\mathrm{C} 57 \mathrm{Bl} / \mathrm{J} 6$ blastocysts and 41 chimeric animals were born, of which 36 were males. The majority of the males showed $>95 \%$ contribution from ES cells on the basis of agouti coat color, and 27 males were test mated to C57Bl/6J females to check for germ-line transmission lagouti pups indicate ES cell contribution to germ cell formation of which $50 \%$ should carry the mutant c-myc allele). As shown in Table 1, 18 of the males sired agouti pups, 3 were fertile but sired only black pups, and 6 were infertile. Of the six infertile animals, two were found to have ovo-testes at autopsy. Germ-line transmission was obtained for each of the targeted clones (Table 1). All subsequent breeding and analysis was carried out in duplicate on two clones that resulted from separate targeting events, clone 6 and clone 10. Agouti offspring of chimeric males were tested by Southern analysis of tail DNA for the presence of the mutant c-myc allele, and as expected, $50 \%$ of the offspring carried the mutant allele.

Homozygous c-myc mutant mice die on or before 10.5 days of gestation

To assess the viability of conceptuses homozygous for the mutant allele, mating pairs of heterozygous animals were set up and the offspring were analyzed. Of 303 offspring tested from both clones, 119 pups were wild type, 184 were heterozygous, and none were homozygous for the c-myc mutation. For a homozygous lethal phenotype, the anticipated wild type-to-heterozygous ratio is $1: 2$, whereas our observed ratio was $1: 1.6$. Test matings showed that the mutant allele could be transmitted equally well through the male or female germ line.

Table 1. Summary of c-myc chimera breeding data

\begin{tabular}{|c|c|c|c|c|c|c|c|c|c|}
\hline \multirow{3}{*}{$\begin{array}{l}\text { Targeted } \\
\text { clone }\end{array}$} & \multirow{3}{*}{$\begin{array}{l}\text { Blastocysts } \\
\text { injected }\end{array}$} & & & \multicolumn{6}{|c|}{ Breeding analysis of chimeras } \\
\hline & & \multicolumn{2}{|c|}{ Chimeras born } & \multirow[b]{2}{*}{ infertile } & \multirow[b]{2}{*}{ germ line } & \multirow[b]{2}{*}{ chimera } & \multicolumn{2}{|c|}{ Offspring } & \multirow[b]{2}{*}{ non-germ line } \\
\hline & & $\mathrm{F}$ & M & & & & black & agouti & \\
\hline \multirow[t]{3}{*}{3} & 18 & 0 & 4 & 0 & 3 & AN7 & 0 & 3 & 1 \\
\hline & & & & & & AN8 & 0 & 13 & \\
\hline & & & & & & AN 10 & 0 & 13 & \\
\hline 4 & 20 & 0 & 2 & 1 & 1 & AN6 & 0 & 7 & 0 \\
\hline 5 & 17 & 2 & 5 & 2 & 1 & AN1 & 9 & 2 & 1 \\
\hline \multirow[t]{5}{*}{6} & 25 & 2 & 10 & 1 & 5 & $\mathrm{AN} 12$ & 0 & 23 & 1 \\
\hline & & & & & & AN13 & 0 & 11 & \\
\hline & & & & & & AN 16 & 0 & 9 & \\
\hline & & & & & & AN21 & 0 & 15 & \\
\hline & & & & & & AN22 & 0 & 18 & \\
\hline 8 & - & - & - & 0 & 1 & AN 28 & 0 & 6 & 0 \\
\hline 9 & 25 & 0 & 1 & 0 & 1 & AN27 & 0 & 8 & 0 \\
\hline \multirow[t]{6}{*}{10} & 24 & 1 & 8 & 2 & 6 & AN12 & 8 & 1 & 0 \\
\hline & & & & & & AN 18 & 0 & 12 & \\
\hline & & & & & & AN 19 & 0 & 10 & \\
\hline & & & & & & AN20 & 13 & 12 & \\
\hline & & & & & & AN24 & 4 & 5 & \\
\hline & & & & & & AN26 & 0 & 20 & \\
\hline Total & 109 & 5 & 36 & 6 & 18 & & & & 3 \\
\hline
\end{tabular}


These results indicated that the homozygous c-myc mutation was lethal before testing at 2 weeks of age. This was true both on a $129 / \mathrm{Sv} \times \mathrm{C} 57 \mathrm{Bl} / 6 \mathrm{~J}$ background as well as on an inbred $129 / \mathrm{Sv}$ background. To determine at what stage of development the homozygous animals were dying, pregnant females from matings of heterozygous mice were sacrificed between 9.5 and $14.5 \mathrm{dpc}$ and the embryos were genotyped by Southern analysis of yolk sac DNA. Of 200 embryos surveyed, genotypes could not be determined for 36,6 of which were morphologically normal and 30 abnormal. The data from the remaining/164 genotyped embryos are shown in Table 2. The chi-squared values to test the null hypothesis of a $1: 2: 1$ Mendelian ratio are accepted at 9.5 and 10.5 days of development $(P>0.05)$ but rejected at ages $>10.5$ days. Although homozygous embryos with a beating heart could be identified at 10.5 days of gestation, all were morphologically abnormal and delayed in development in comparison with their littermates. The two homozygous embryos identified after 10.5 days of gestation were severely necrotic. Thus, most, if not all, homozygotes survive to 9.5 days of gestation but do not survive beyond 10.5 days of gestation.

Two independently targeted $\mathrm{c}$-myc mutant clones give a similar embryonic lethal phenotype in both crossbred and inbred animals

Clones 6 and 10 were both examined to ensure that the phenotype observed was not the result of some unexpected mutation that could have occurred during the targeting event and not been detected by Southern analysis. The data shown in Table 2 are a summary of the 9.5- and 10.5-dpc embryos examined from the two different clones. The distribution of wild type, heterozygotes, and homozygotes is similar for both. In both cases, embryos fail to develop beyond the morphological equivalent of 10 days but appear to survive up until that stage. Thus, the phenotype can be attributed to the insertion of the neo gene in c-myc. Although the numbers for the inbred $129 / \mathrm{Sv}$ animals are small, there is no evidence that the embryonic phenotype is different on an inbred background. c-myc homozygous mutant embryos have a generalized delay in development in comparison with their littermates

Table 2 shows that $94 \%$ of homozygotes are morphologically abnormal (scored blind), whereas $12 \%$ and $11 \%$ of the wild-type and heterozygous embryos, respectively, are abnormal. All homozygotes are abnormal by 10.5 days of gestation and $88 \%$ at 9.5 days of gestation. A pairwise comparison was done between homozygous embryos and a representative normal littermate. All embryos were classified according to the system of Brown for embryos between 8.5 and 11 days of development on 15 morphologic criteria (Brown 1990). They include yolk sac circulation, allantois, flexion, heart, caudal neural tube, hindbrain, midbrain, forebrain, otic system, optic system, olfactory system, branchial bars, forelimb, hindlimb, and somite number. For each embryo, the total score is expressed as a percentage of the maximum, with $100 \%$ being $\sim 11$ days of development (Fig. 4). Each homozygote is compared with a representative normal littermate. For the purpose of orientation, the normal littermates of homozygous embryos $1,3,6,14,17,23$, and 33 had 4, 10, 16, 18, 21, 28, and 32 somites, respectively. The earliest time at which delay was observed was when the normal littermates were at the 15-somite stage (embryo 4). The latest time at which homozygotes were indistinguishable morphologically from their littermates was at the 18-somite stage (embryo 11). It should be noted that even within litters, the degree to which developmental retardation occurred was variable (embryos 7-11 inclusive). Nevertheless, there is a relatively small developmental window in which homozygotes begin to lag behind their littermates. The homozygote that progressed farthest in development (embryo 28) reached the 24-somite stage and developed a hindlimb bud; however, this embryo was also delayed compared with its normal littermates and was only half the size (Fig. 6c, below). This narrow developmental window in which c-myc mutant embryos fail suggests that there is some vital c-myc function that is critical for survival beyond this stage. To determine whether any particular organ system was responsible, the average score for either the homozygotes or their normal littermates was calculated for each

Table 2. Genotype of embryos from c-myc heterozygous matings

\begin{tabular}{|c|c|c|c|c|c|c|c|c|c|}
\hline \multirow[b]{2}{*}{ Phenotype/genotype } & \multicolumn{3}{|c|}{ Normal } & \multicolumn{3}{|c|}{ Abnormal } & \multicolumn{3}{|c|}{ Total } \\
\hline & $+1+$ & $+1-$ & $-1-$ & $+1+$ & $+1-$ & $-1-$ & $+1+^{a}$ & $+1-{ }^{a}$ & $-1-{ }^{a}$ \\
\hline All embryos genotyped & 37 & 81 & 2 & 5 & 10 & 29 & $42(26)$ & $91(55)$ & 31 (19) \\
\hline 9.5 days of gestation & 12 & 21 & 2 & 0 & 3 & 14 & $12(24)$ & $24(46)$ & $16(30)$ \\
\hline 10.5 days of gestation & 12 & 40 & 0 & 4 & 5 & 13 & $16(22)$ & $45\lfloor 60\}$ & $13\langle 18\}$ \\
\hline$>10.5$ days of gestation & 13 & 20 & 0 & 1 & 2 & 2 & $14(37)$ & $22(58)$ & $2\langle 5\rangle$ \\
\hline Crossbred $(129 \times \mathrm{C} 57 \mathrm{Bl})^{\mathrm{b}}$ & 22 & 44 & 1 & 4 & 6 & 24 & $26(25)$ & $50(50)$ & $25(25)$ \\
\hline Inbred $129^{\mathrm{b}}$ & 2 & 17 & 1 & 0 & 2 & 3 & $2[8 \mid$ & $19(76)$ & $4(16)$ \\
\hline Clone $6^{\mathrm{b}}$ & 8 & 32 & 1 & 1 & 5 & 11 & $9(15)$ & $37(64)$ & $12(21)$ \\
\hline Clone $10^{\mathrm{b}}$ & 16 & 29 & 1 & 3 & 3 & 16 & $19(28)$ & $32(47)$ & $17(25)$ \\
\hline
\end{tabular}

${ }^{a}$ Numbers in parentheses are percentages of total embryos in that class.

bonly embryos of 9.5 or 10.5 days of gestation are included. 


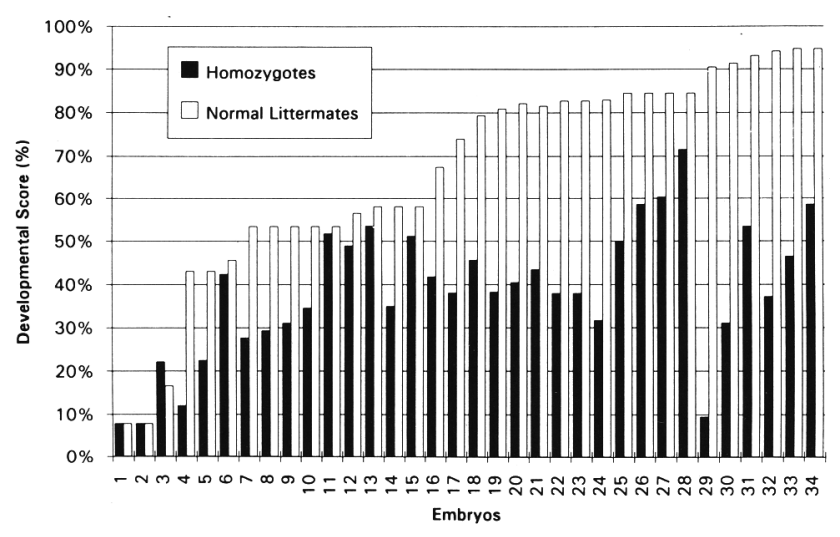

Figure 4. Comparison of c-myc homozygous embryos with their normal littermates on the basis of average developmental age. Each homozygous embryo was scored on some or all of 15 developmental criteria according to the system of Brown (1990). A normal littermate was also scored according to the same system. The total score for each embryo is expressed as a percentage of the total possible score for an embryo at 11 days of development. The homozygous embryos are numbered from 1 to 34 and are graphed next to a representative normal littermate. In some cases, more than one homozygote was present in a litter, and each has been compared with the same normal littermate.

category in the graph in Figure 5. The lines are roughly parallel, indicating that no organ system is specifically underdeveloped in the homozygotes. The exception is the category of yolk sac circulation, which appears decreased in homozygotes. This may reflect the particular stage at which the embryos are ceasing to grow. Alternatively, it may indicate a primary extraembryonic cause for embryonic lethality.

\section{Pathological abnormalities in c-myc homozygous mutant embryos}

The previous analysis dealt with a generalized delay in development. The embryos also showed pathological abnormalities. These consisted of either abnormalities that are never seen in normal embryos or a developmental event that was delayed compared with the developmental stage of the embryo. Five different morphologic phenotypes were consistently observed and the penetrance is documented in Table 3. Examples of embryos with each of the described phenotypes are shown in Figure 6. The homozygous embryos were consistently one-third to three-fourths the size of their littermates. The phenotype labeled delay refers to embryos that were delayed in development in comparison with their littermates in multiple organ systems consistent with a generalized retardation (Fig. 6c). This element of the phenotype often overlaps with size, as considerable growth is occurring at this stage of embryogenesis. In general, the retarded embryos were also small; however, in some embryos the developmental stage was the same but the size was reduced (Fig. 6a). The heart abnormality consisted of enlargement and the pericardium abnormality was a di- lated, fluid-filled pericardium (Fig. 6d,e). The phenotype labeled turning was evidenced by embryos that have developed beyond the point at which turning should be complete and yet the posterior half of the embryo had not completely turned (Fig. 6d). The neural defect shows either a failure or retardation of neural tube closure (Fig. 6b).

Each of these abnormalities is much more common in homozygous embryos than in wild-type or heterozygous littermates. The size and delay occur in $86 \%$ and $89 \%$ of the homozygous embryos, respectively. This high incidence is the result of the lethality of the mutation and cannot be considered as specific to c-myc in comparison with other embryonic lethals. The other abnormalities may reflect the specific lack of $\mathrm{c}-m y c$ function. The heart phenotype was present in $34 \%$ of the homozygote embryos but only $1 \%$ of the nonhomozygotes. The pericardium abnormality was only twice as frequent in the homozygotes as in the nonhomozygote population $11 \%$ and $5 \%$, respectively). The turning and neural phenotypes were present in $33 \%$ and $27 \%$ of the homozygote embryos, respectively, in comparison with $1 \%$ of the nonhomozygotes.

We also examined the embryos at the histological level. Although various abnormalities were seen in homozygotes, none was sufficiently consistent to be useful in determining the exact cellular deficit created by lack of the c-Myc protein. In general, homozygotes showed normal organ architecture and cellular morphology; however, cell number cannot be assessed accurately by this type of analysis. Figure 6 shows sagittal sections of homozygous embryo $18(\mathrm{~h})$ and its normal littermate (f). Because this embryo is delayed compared with its littermate, a normal embryo at a similar stage of development

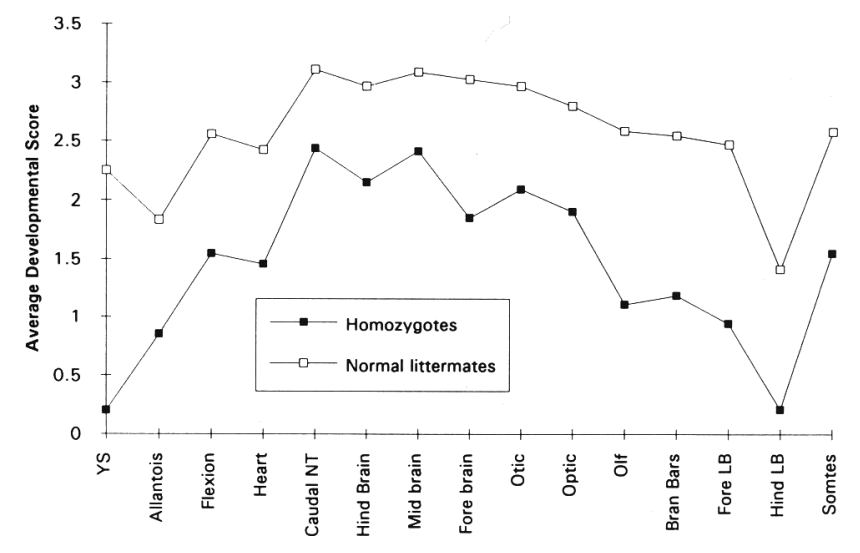

Figure 5. Comparison of c-myc homozygous embryos with their normal littermates on specific developmental criteria. Normal and homozygous embryos were scored for yolk sac circulation, allantois, flexion, heart, caudal neural tube, hindbrain, midbrain, forebrain, otic system, optic system, olfactory system, branchial bars, forelimb, hindlimb, and somite number (Brown 1990). Each category is scored between 0 and 3 or 4, depending on the category. For each category, the score of either the homozygotes or their normal littermates was averaged and plotted. 
Table 3. Penetrance of the c-myc mutant phenotype on the basis of genotype

\begin{tabular}{|c|c|c|c|c|c|c|}
\hline & Heart & Pericardium & Turning & Neural & Size & Delay \\
\hline \multicolumn{7}{|c|}{ Wild type and heterozygotes } \\
\hline Present & 1 & 7 & 2 & 1 & 9 & 12 \\
\hline Total number of embryos & 142 & 142 & 140 & 140 & 142 & 142 \\
\hline Frequency $(\%)$ & 1 & 5 & 1 & 1 & 6 & 8 \\
\hline \multicolumn{7}{|c|}{ Homozygotes } \\
\hline Present & 12 & 4 & 9 & 8 & 30 & 31 \\
\hline Total number of embryos & 35 & 35 & 27 & 30 & 35 & 35 \\
\hline Frequency $\{\%\}$ & 34 & 11 & 33 & 27 & 86 & 89 \\
\hline
\end{tabular}

The nature of each element of the phenoype is described in the text. Each of the genotyped embryos was scored for the presence or absence of the morphological anormality. In some cases, e.g., turning and neural tube closure, the total number of embryos scored is lower. This is the result of embryos that had a general delay in development. Turning and neural tube closure could not be assessed because the developmental stage of the embryo in general had not progressed beyond the stages at which these events would be expected to be completed.

(normal littermate of embryo 6) is also shown for comparison $(\mathrm{g})$. A high percentage of the heterozygous and wild-type embryos are also abnormal $(12 \%$ and $11 \%$, respectively). Because these abnormal embryos occur with similar frequencies in wild-type and heterozygous populations, their appearance is unlikely to be associated with the genotype of the embryo. It could, however, be part of the heterozygous maternal phenotype discussed below.

\section{c-myc heterozygous females have reduced fertility}

The number of embryos in heterozygous females that could not be genotyped was high at 36 of 200 . Of those $36,70 \%$ were not genotyped because no embryonic tissue was available owing to embryonic resorption. The question arises whether these resorptions are part of the c-myc homozygous embryonic phenotype or the result of some other factor. Homozygotes can be reliably detected up to 10.5 days of gestation. If the embryos of this age only are pooled, then it is possible to test statistically whether the resorptions are likely to be homozygotes. If we assume that the genotype of the resorbing embryos has a similar distribution to those for which a genotype was available, the resorptions can be excluded and the chi-squared test applied. The alternate hypothesis that the resorbing embryos are all homozygotes can also be tested by including all resorptions as homozygotes. The chi-squared value when the resorptions are excluded is 1.15 , which indicates that the hypothesis is accepted. Conversely, if the resorptions are assumed to contain only homozygous embryos, the chi-squared value of 6.47 results in rejection of this hypothesis at the $5 \%$ level. Thus, it would appear that these resorptions are independent of the genotype of the embryo. Because these are crossbred animals, the resorption rate of animals with the same genetic background is difficult to measure. Instead, we examined the breeding data from the inbred $129 / \mathrm{Sv}$ mice heterozygous for the c-myc mutation. The results are shown in Table 4 . The average litter size of $4.2 \pm 2.1$ when only the male is heterozygous is signifi- cantly different at the $5 \%$ level from a litter size of $3.61 \pm 1.6$ when both parents are heterozygous (corrected for homozygous losses). On a smaller sample, when only the female is heterozygous, the average litter size was $3.2 \pm 2.1$, similar to that found in heterozygous mating pairs. Thus, reduced litter size occurs when the female is heterozygous for the c-myc mutation. Therefore, part of the c-myc mutant phenotype is reduced fertility in heterozygous females owing to resorption of embryos before $9.5 \mathrm{dpc}$.

\section{Discussion}

We have mutated c-myc in ES cells by using gene targeting. The mutation is a null allele as demonstrated by the failure to detect c-Myc protein by radioimmunoprecipitation in homozygous mutant ES cell lines. A survey of 200 embryos showed that homozygous c-myc mutant embryos survive up to 9.5 days but not past 10.5 days of gestation. Homozygotes can first be identified as abnormal when their littermates are at the 15-somite stage, whereas all homozygotes were delayed in development by the 18 -somite stage. The most advanced homozygote progressed to the 24-somite stage and developed a hindlimb bud. Pathological abnormalities observed in homozygotes included reduced size, enlarged hearts, dilated fluid-filled pericardia, and a delay or failure in closure of the neural tube and turning of the embryo. In addition, heterozygous females have reduced fertility owing to embryonic resorption of $14 \%$ of the implanted embryos by 9.5 days of gestation. The resorptions are independent of the genotype of the embryo.

\section{Why do the embryos fail?}

At this stage of embryogenesis, the most important organs for survival are involved in the nutrition of the embryo. This includes the fetal and maternal placenta and an adequate embryonic circulation. The c-myc mutant embryos are small and retarded in development compared with their littermates, which would be consistent 

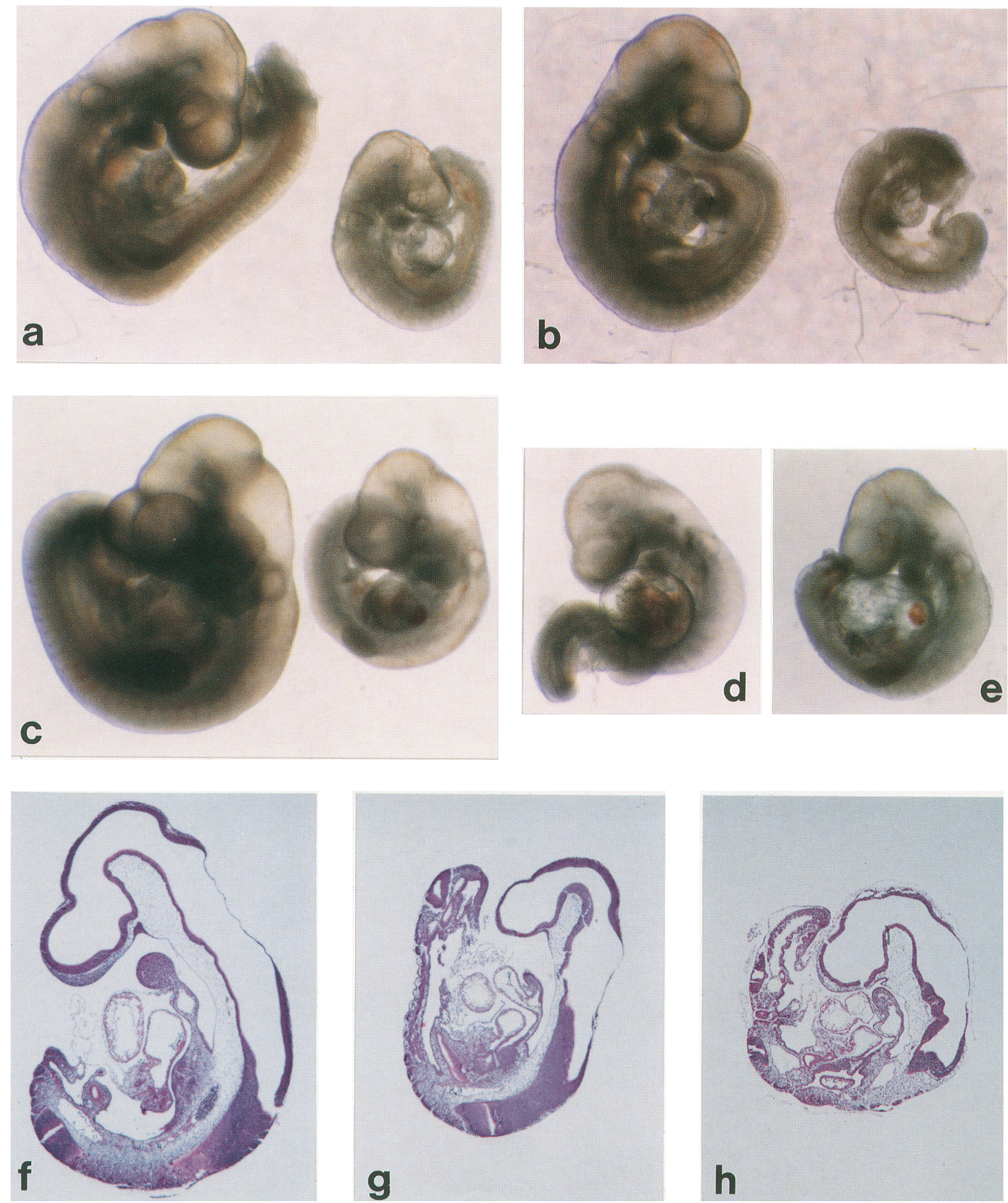

Figure 6. Phenotype of $\mathrm{c}-m y c$ homozygous embryos. $|A|$ Embryo 5 (right) and a normal littermate showing reduced size but similar developmental stage. $(B)$ Embryo 14 (right) and normal littermate showing a failure of the neural tube to close in the hind-, mid-, and forebrain despite the embryo being completely turned and beyond the stage at which neural tube closure should be complete. $(C)$ Embryo 28 (right) and normal littermate showing a generalized delay in development and small size. This embryo was the most advanced homozygote. (D) Embryo 33 showing a dilated fluid filled pericardium and a failure of the hind end of the embryo to turn. $(E)$ Embryo 27 showing an enlarged heart. $\{F\}$ Sagittal section of normal littermate of embryo 18. (G) Sagittal section of the normal littermate of embryo 6, which is at the same developmental age as the homozygous embryo 18. (H) Sagittal section of homozygous embryo 18 . 
Table 4. Breeding performance of inbred $129 \mathrm{SV}$ $c$-myc heterozygotes

\begin{tabular}{lcccc}
\hline Male & Female & $\begin{array}{l}\text { Total number } \\
\text { of pups }\end{array}$ & $\begin{array}{l}\text { Number of } \\
\text { litters }\end{array}$ & $\begin{array}{l}\text { Average } \\
\text { litter size }\end{array}$ \\
\hline$+/-$ & $+/+$ & 190 & 42 & $4.5 \pm 2.1$ \\
$+/-$ & $+/-$ & 103 & 38 & $3.6 \pm 1.6^{\mathrm{a}}$ \\
$+/+$ & $+/-$ & 29 & 9 & $3.2 \pm 2.1$ \\
\hline
\end{tabular}

${ }^{a}$ Corrected for loss of homozygous embryos.

with malnutrition. Yolk sac vascularity and vitelline vessel formation is reduced on average compared with normal littermates. In most homozygotes, yolk sac vascularity is normal for the developmental stage of the embryo but reduced by the criterion of gestational age. The homozygous embryos also show cardiac abnormalities with enlarged hearts and dilated fluid-filled pericardia. Wild-type embryos also show this abnormality, although much less commonly, so it remains to be determined whether this element of the phenotype is specific for embryonic heart failure and whether that heart failure is a direct or indirect result of the null c-myc allele. Two experiments will help to resolve these alternate possibilities. The homozygous cell lines can be used to generate chimeras that have wild-type extraembryonic tissue, because ES cell lines contribute poorly to this lineage but contribute significantly to the embryo proper (Beddington and Robertson 1989). If these chimeras show a similar phenotype to $c-m y c$ homozygotes, an extraembryonic cause for the lethality can be eliminated. To determine whether the lack of $c-m y c$ expression is primary to the cardiac defect, rescue can be attempted by expressing c-myc specifically in the myocardium of $\mathrm{c}-\mathrm{myc} \mathrm{mu}-$ tant homozygotes. A transgenic animal expressing c-myc only in the heart has been reported and could be bred to the c-myc mutant mice to determine whether rescue can be achieved (Swain et al. 1987).

\section{Reduced fertility in female heterozygotes}

Heterozygous c-myc mutant female mice have reduced fertility and a high rate of embryonic resorption by 9.5 dpc. c-myc is expressed at high levels in the peripheral maternal decidual tissue at 6.5 and 7.5 days of development, which coincides with mitotic cells within the implantation site (Downs et al. 1989). Embryonic resorption may represent a failure of adequate proliferation in the maternal decidua owing to reduced c-myc expression. This effect appears to be unrelated to the genotype of the embryos. Of the embryos that survive, $11.5 \%$ of the nonhomozygous embryos fail later in development. This, too, may be a maternal effect, as heterozygotes and wild types are equally represented, although we have not documented the frequency of embryonic failure in our wild-type population.

\section{Function of $c$-myc as revealed by homozygous mutant embryos and cell lines}

A great deal of information has been gathered about c-myc function in tumorigenesis, in transgenic mice, and in tissue culture. In all of these systems, c-myc appears to have a role in cellular proliferation. Deregulation can lead to immortality and tumorigenesis, and reduced expression using antisense methodologies can lead to differentiation and cessation of division. This is the first report of the behavior of c-myc-deficient cells, which clearly are capable of extensive cell division. The homozygous mutant cell line proliferates in culture, and the homozygous embryos develop to a stage at which considerable cell division has occurred. Thus, although c-myc expression is associated with dividing cells, it does not appear to be required for proliferation in ES cells or in the embryo before $8.5 \mathrm{dpc}$.

One explanation is that other members of the Myc protein family could be rescuing these cells. c-Myc is one of a family of proteins with similar structure (DePinho et al. 1991) and DNA-binding specificity (Alex et al. 1992; Papoulas et al. 1992), which often leads to speculation that the functions of family members might overlap. All heterodimerize with Max protein (Blackwood and Eisenman 1991) and cotransform rat embryo fibroblasts (DePinho et al. 1987). In addition, retroviral infection of $E \mu-$ $\mathrm{N}$-ras transgenic mice accelerates lyphomagenesis by activating either $c-m y c$ or $\mathrm{N}-m y c[68 \%$ and $13 \%$ or the clonal tumors, respectively (Haupt et al. 1992)]. Thus the capacity for extensive cell proliferation in the absence of $c-m y c$ may indicate that N-myc can substitute functionally for c-myc up to 10 days of development. The hypothesis can be tested by using homologous recombination in ES cells to replace c-myc-coding sequence with $\mathrm{N}$-myc but maintain the $c-m y c$ regulatory regions and chromosomal location. Survival of the embryos beyond 10 days of development would indicate that $\mathrm{N}$-myc-coding sequences can perform c-myc functions when expressed appropriately.

An alternate hypothesis is consistent with the data but does not invoke $\mathrm{N}-m y c$ rescue. $\mathrm{c}-m y c$ expression is associated with, but not necessary for, cell division. It is, however, necessary for embryonic survival beyond 10 days of development. In addition, c-myc is rapidly induced by growth factors and is at a low level in quiescent cells. This suggests a role in signal transduction, and it is reasonable to assume that the signal transduced is one that leads to, but is not exclusively responsible for, cell division. Thus, we propose a model in which c-myc function accelerates the rate at which events involved in cell division occur. Cells in culture would be expected to survive. c-myc-deficient cells would also be able to proliferate sufficiently to populate the embryo but be unresponsive to growth factors signaling a proliferative burst necessary for normal development. This would be expected to generate pathological abnormalities first in the heart and in the extraembryonic tissue, but the neural tube abnormalities and the failure to turn may be the result of a similar phenomenon. The homozygous c-myc mutant ES cell lines will be useful for generating chimeras to test this hypothesis.

The use of gene targeting in ES cells has revealed that although c-myc is not essential for cellular proliferation 
or differentiation, it is necessary for normal embryonic development. With these tools in hand, it should be possible to identify specifically where and when c-myc expression is critical to embryonic survival.

\section{Materials and methods}

\section{Constructs for homologous recombination}

The targeting construct contains $10.6 \mathrm{~kb}$ of the mouse genomic c-myc sequence extending from the NheI site in intron 1 to an $X b a I$ site $3^{\prime}$ of the coding region. The coding sequence is interrupted by a neo cassette inserted in the EcoRV site in exon 2 in the same transcriptional orientation as c-myc. An HSV-TK type 1 gene is located $5^{\prime}$ to the c-myc sequences. The $3-\mathrm{kb} B a m H I$ fragment containing the HSV-TK gene (pucTK1) was cloned into the BamHI site in pUC19 (Pharmacia) to give pAD19. The 900-bp NheI-XbaI c-myc fragment from intron 1 was cloned into the $\mathrm{XbaI}$ site of $\mathrm{pAD} 19$ in the opposite orientation as the TK to give pAD21. A neo cassette, Pol2neobpA / courtesy of Phil Soriano, Baylor College of Medicinel, was excised with XhoI and Sall, filled with Klenow, and ligated into the EcoRV site in exon 2 of the 9.7-kb XbaI c-myc fragment to give pAD27. The c-myc $X b a I$ fragment containing the neo cassette was excised and inserted in the $X b a I$ site of pAD21 to give the targeting vector pAD30 (Fig. 1). The targeting vector for the second allele was constructed in a similar manner, except a gpt cassette with the same promoter and polyadenylation sequence as the neo cassette was inserted into the EcoRV site. Both vectors were linearized with $S a l l$ before electroporation.

\section{Tissue culture, gene targeting, and blastocyst injection}

The ES cell line $\mathrm{ABl}$ was derived from a black agouti $129 \mathrm{~Sv}$ embryo using techniques described previously (Robertson 1987). The AB2.1 cell line is similar but is $\mathrm{HPRT}^{-}$as it was derived from TG4 mice (Kuehn et al. 1987). ES cell lines were cultured as described (McMahon and Bradley 1990) on a monolayer of mitotically inactivated STO fibroblasts, which were transfected with a neo and a leukemia inhibitory factor (LIF) expression construct (SNL 76/7). Cells were trypsinized, resuspended at a concentration of $10^{7}$ cells per $0.9 \mathrm{ml}$ of PBS, and electroporated with $25 \mu \mathrm{g}$ of linearized DNA at $230 \mathrm{~V}, 500 \mu \mathrm{F}$, using a Bio-Rad Gene Pulser. Cells were plated at $10^{7}$ cells per $10-\mathrm{cm}$ feeder plate. Selection with HAT $100 \mu \mathrm{M}$ sodium hypoxanthine, $0.4 \mu \mathrm{M}$ aminopterin, and $16 \mu \mathrm{m}$ thymidine added $48 \mathrm{hr}$ after electroporation; GIBCO) and FIAU $(0.2 \mu \mathrm{M}$ 1-[2-deoxy, 2 -fluoro- $\beta$-D-arabinofuranosil-|-5-iodouracil added after $24 \mathrm{hr}$ ) or G418 $(180 \mu \mathrm{g} / \mathrm{ml}$ of active ingredient after $24 \mathrm{hr})$ and FIAU was maintained for 10 days. Resistant colonies were picked into individual wells of 96-well feeder plates, and an aliquot was retained for PCR analysis. C57B1/6J blastocysts were isolated at day 3.5 and injected with $\sim 15$ ES cells as described previously (Bradley 1987).

\section{PCR screening of recombinant clones and Southern blot analysis}

A small aliquot of cells from each clone was retained at picking and combined in pools of six for PCR analysis. Cells were lysed in $20 \mu \mathrm{l}$ of PCR lysis buffer (1× PCR buffer, $0.45 \%$ NP.40, $0.45 \%$ Tween $20,50 \mu \mathrm{g} / \mathrm{ml}$ of proteinase $\mathrm{K}$, incubated at $60^{\circ} \mathrm{C}$ for $1 \mathrm{hr}$, and then at $90^{\circ} \mathrm{C}$ for $10 \mathrm{~min}$ to inactivate the proteinase $\mathrm{K}$. One-quarter of the sample was amplified in a final volume of $50 \mu \mathrm{l}$ in $1 \times$ PCR buffer $110 \mathrm{~mm}$ Tris- $\mathrm{HCl}$ at $\mathrm{pH} 8.3,50 \mathrm{mM} \mathrm{KCl}$, $4.5 \mathrm{~mm} \mathrm{MgCl} l_{2}, 1 \mathrm{~mm}$ each dNTP, $1 \mu \mathrm{M}$ each primer, and 50
$\mathrm{U} / \mathrm{ml}$ of $\mathrm{Taq}$ polymerase. Amplifications were carried out for 35 cycles of $30 \mathrm{sec}$ at $93^{\circ} \mathrm{C}, 30 \mathrm{sec}$ at $55^{\circ} \mathrm{C}$, and $2 \mathrm{~min}$ at $72^{\circ} \mathrm{C}$ in a Perkin-Elmer Cetus DNA Thermal Cycler. Oligonucleotide 1622 (5'-GGTGCATTTCTGACAGCCTGGGACC-3') is derived from genomic c-myc immediately upstream of the NheI site in intron A (nucleotides 1436-1460) and oligonucleotide 1623 (5'-TTTACGGAGCCCTGGCGCTCGATGT - 3') from the RNA polymerase II promoter in the neo construct. Oligonucleotides 1622 and 1623 were used to generate a $1.26-\mathrm{kb}$ fragment unique to targeted clones (Fig. 1). Individual clones from six positive pools were screened by PCR, and the positive clones were expanded. Isolation of genomic DNA from cells and tails for Southern analysis was done by standard methods /Southern 1975). Probes used for the Southern analysis include a 650-bp EcoRV-BglI fragment from exon 2 (Fig. 1, probe A) and a 1.9-kb XhoI-KpnI fragment from exon 3 (Fig. 1, probe B).

\section{Radioimmunoprecipitation of c-Myc protein}

Radioimmunoprecipitation was carried out as described previously (Spotts and Hann 1990). Briefly, cells were passaged six times without feeders on gelatin-coated plates. Cells in logphase growth were radiolabeled with $350 \mu \mathrm{C}$ of $\left[{ }^{35} \mathrm{~S}\right] \mathrm{methionine}$ (ICN Trans ${ }^{35} \mathrm{~S}$-label) in $1 \mathrm{ml}$ of methionine-free medium (GIBCO Laboratories) for $20 \mathrm{~min}$ at $37^{\circ} \mathrm{C}$ in $5 \% \mathrm{CO}_{2}$. The amount of $\left[{ }^{35} \mathrm{~S} \mid\right.$ methionine incorporated into cellular proteins was measured by TCA precipitation for each cell line. For the ES cell lines, $35 \times 10^{6} \mathrm{cpm}$ per sample was used for immunoprecipitation, and for the feeders that express higher levels of c-myc, $15 \times 10^{6} \mathrm{cpm}$ was used. c-myc was immunoprecipitated with an affinity-purified rabbit anti-mouse c-myc peptide antibody (carboxy-terminal 12-mer). For the blocking experiment, $10 \mu \mathrm{g}$ of peptide was preincubated with $5 \mu \mathrm{g}$ of antibody for $2 \mathrm{hr}$ on ice and then added to the preclarified lysate as was done for the radioimmunoprecipitation procedure.

\section{Analysis of embryos}

Embryos were harvested from timed mating between crossbred (C57Bl/6) and 129Sv) or inbred 129Sv mice heterozygous for the c-myc mutation between 9.5 and 13.5 dpc. Embryos were dissected free of the deciduum and the yolk sac, the amnion was removed, and the embryos were photographed and classified on 15 criteria of morphologic development as described by Brown (1990). The yolk sac was used for DNA analysis. Yolk sacs were suspended in $50 \mu$ l of cell lysis buffer $(10 \mathrm{mM}$ Tris at $\mathrm{pH} 7.5,10$ mM EDTA, $10 \mathrm{~mm} \mathrm{NaCl}, 0.5 \%$ Sarkosyl) with $1 \mathrm{mg} / \mathrm{ml}$ of proteinase $\mathrm{K}$ and incubated on a rotator overnight at $60^{\circ} \mathrm{C}$. Samples were either processed immediately or stored at $-20^{\circ} \mathrm{C}$. The DNA was precipitated with $100 \mu \mathrm{I}$ of cold ethanol containing $1.5 \mu \mathrm{l}$ of $5 \mathrm{M} \mathrm{NaCl}$, spun in a microcentrifuge for $10 \mathrm{~min}$, and washed twice with $70 \%$ ethanol. The DNA was dried and resuspended in $25 \mu \mathrm{l}$ of TE buffer. Yields were variable, but previous testing indicated that $1 \mu \mathrm{g}$ was sufficient for Southern analysis. All homozygous embryos were fixed in $4 \%$ paraformaldehyde, dehydrated through graded alcohols and xylene, and embedded in paraffin. Embryos were serially sectioned and stained with hematoxylin and eosin.

\section{Acknowledgments}

We thank Jerry Adams for the c-myc genomic clone, Luis Parada for sectioning some of the embryos, and Brigid Hogan for her advice and encouragement. A.C.D. was funded by the Medical Research Council of Canada. This work was funded by grants 
from the National Institutes of Health (NIH) (Child Health and Human Development) to A.B., and NIH CA-47399 to S.R.H. A.B. is a Leukemia Society Fellow.

The publication costs of this article were defrayed in part by payment of page charges. This article must therefore be hereby marked "advertisement" in accordance with 18 USC section 1734 solely to indicate this fact.

\section{References}

Adams, J.M., A.W. Harris, C.A. Pinkert, L.M. Corcoran, W.S. Alexander, S. Cory, R.D. Palmiter, and R.L. Brinster. 1985. The cc oncogene driven by immunoglobulin enhancers induces lymphoid malignancy in transgenic mice. Nature 318: 533-538.

Alex, R., O. Sozeri, S. Meyer, and R. Dildrop. 1992. Determination of the DNA sequence recognized by the bHLHp domain of the N-myc protein. Nucleic Acids Res. 20: 2257-2263.

Beddington, R.S.P. and E.J. Robertson. 1989. An assessment of the developmental potential of embryonic stem cells in the midgestation mouse embryo. Development 105: 733-737.

Bentley, D.L. and M. Groudine. 1986. A block to elongation is largely responsible for decreased transcription of c-myc in differentiated HL60 cells. Nature 321: 702-706.

Bernard, O., S. Cory, S. Gerondakis, E. Webb, and J.M. Adams. 1983. Sequence of the murine and human cellular myc oncogenes and two modes of myc transcription resulting from chromosome translocation in B lymphoid tumors. $E M B O F$. 2: 2375-2383.

Blackwood, E.M. and R.N. Eisenman. 1991. Max: A helix-loophelix zipper protein that forms a sequence specific DNAbinding complex with myc. Science 251: 1211-1217.

Bradley, A. 1987. Production and analysis of chimeric mice. In Teratocarcinomas and embryonic stem cells: A practical approach (ed. E.J. Robertson), pp. 113-151. IRL Press, Oxford, England.

Brown, N.A. 1990. Routine assessment of morphology and growth: Scoring systems and measurement of size. In Postimplantation mammalian embryos: A practical approach |ed. A.J. Copp and D.L. Cockroft|, pp. 93-108. Oxford University Press, New York.

Cole, M.D. 1986. The myc oncogene: Its role in transformation and differentiation. Annu. Rev. Genet. 20: 361-384.

Coppola, J.A., J.M. Parker, G.D. Schuler, and M.D. Cole. 1989. Continued withdrawal from the cell cycle and regulation of cellular genes in mouse erythroleukemia cells blocked in differentiation by the c-myc oncogene. Mol. Cell. Biol. 89: 1714-1720.

DePinho, R.A., K.S. Hatton, A. Tesfaye, G.D. Yancopoulos, and F.W. Alt. 1987. The human myc gene family: Structure and activity of L-myc and an L-myc pseudogene. Genes \& Dev. 1: $1311-1326$.

DePinho, R.A., N. Schreiber-Agus, and F.W. Alt. 1991. Myc family oncogenes in the development of normal and neoplastic cells. Adv. Cancer Res. 57: 1-46.

Dmitrovsky, E., W.M. Kuehl, G.F. Hollis, I.R. Kirsch, T.P. Bender, and S. Segal. 1986. Expression of a transfected human c-myc oncogene inhibits differentiation of a mouse erythroleukemia cell line. Nature 322: 748-750.

Downs, K.M., G.R. Martin, and J.M. Bishop. 1989. Contrasting patterns of myc and $\mathrm{N}-m y c$ expression during gastrulation of the mouse embryo. Genes \& Dev. 3: 860-869.

Eilers, M., S. Schirm, and J.M. Bishop. 1991. The myc protein activates transcription of the $\alpha$-prothymosin gene. EMBO $J$. 10: $133-141$.
Enrietto, P.J. 1987. The myc oncogene in avian and mammalian carcinogenesis. Cancer Surv. 6: 85-99.

Griep, A.E. and H. Westphal. 1988. Antisense myc sequences induce differentiation of F9 cells. Proc. Natl. Acad. Sci. 85: 6806-6810.

Hann, S.R., M.W. King, D.L. Bentley, C.W. Anderson, and R.N. Eisenman. 1988. A non-AUG translational initiation in c-myc exon 1 generates an $\mathrm{N}$-terminally distinct protein whose synthesis is disrupted in Burkitt's lymphomas. Cell 52: 185-195.

Hauguel-Mouzon, S., P. Csermely, G. Zoppini, and C.R. Kahn. 1992. Quantitative dissociation between EGF effects on c-myc and c-fos gene expression DNA synthesis and epidermal growth factor receptor tyrosine kinase activity. $J$. Cell. Physiol. 150: 180-187.

Haupt, Y., W.S. Alexander, G. Barri, S.P. Klinken, and J.M. Adams. 1991. Novel zinc finger gene implicated as myc collaborator by retrovirally accelerated lymphomagenesis in Emu. myc transgenic mice. Cell 65: 753-763.

Haupt, Y., A.W. Harris, and J.M. Adams. 1992. Retroviral infection accelerates $\mathrm{T}$ lymphomagenesis in Emu-N-ras transgenic mice by activating c-myc or N-myc. Oncogene 7: $981-$ 986.

Holt, J.T., R.L. Redner, and A.W. Nienhuis. 1988. An oligomer complementary to c-myc mRNA inhibits proliferation of HL-60 promyelocytic cells and induces differentiation. Mol. Cell. Biol. 8(2): 963-973.

Keath, E.J., A. Kelekar, and M.D. Cole. 1977. Transcriptional activation of the translocated $c$-myc oncogene in mouse plasmacytomas: Similar RNA levels in tumor and proliferating normal cells. Cell 37: 521-528.

Kelly, K., B.H. Cochran, C.D. Stiles, and P. Leder. 1983. Cellspecific regulation of the c-myc gene by lymphocyte mitogens and platelet-derived growth factor. Cell 35: 603-610.

Klemsz, M.J., L.B. Justement, E. Palmer, and J.C. Cambier. 1989. Induction of c-fos and c-myc expression during B cell activation by IL- 4 and immunoglobulin binding ligands. $J$. Immunol. 143: 1032-1039.

Kozak, M. 1986. Point mutations define a sequence flanking the AUG initiator codon that modulates translation by eukaryotic ribosomes. Cell 44: 283-292.

Kuehn, M.R., A. Bradley, E.J. Robertson, and M.J. Evans. 1987. A potential animal model for Lesch-Nyhan syndrome through introduction of HPRT mutations into mice. Nature 326: 295-298.

Land, H., L.F. Parada, and R.A. Weinberg. 1983. Tumorigenic conversion of primary embryo fibroblasts requires at least two cooperating oncogenes. Nature 304: 596-602.

Langdon, W.Y., A.W. Harris, S. Cory, and J.M. Adams. 1986. The c-myc oncogene perturbs B lymphocyte development in Emu-myc transgenic mice. Cell 47: 11-18.

Lee, W.M.F., M. Schwab, D. Weataway, and H.E. Varmus. 1985. Augmented expression of normal c-myc is sufficient for cotransformation of rat embryo cells with a mutant ras gene. Mol. Cell. Biol. 5: 3345-3356.

Lüscher, B. and R.N. Eisenman. 1990. New light on Myc and Myb. Part I. Myc. Genes \& Dev. 4: 2025-2035.

Mansour, S.L., K.R. Thomas, and M.R. Capecchi. 1988. Disruption of the protocogene int- 2 in mouse embryo-derived stem cells: A general strategy for targeting mutations to non-selectable genes. Nature 336: 348-352.

McMahon, A.P. and A. Bradley. 1990. The Wnt-1 (int-1) protooncogene is required for development of a large region of the mouse brain. Cell 62: 1073-1085.

Morrow, M.A., G. Lee, S. Gillis, G.D. Yancopoulos, and F.W. Alt. 1992. Interleukin-7 induces $\mathrm{N}$-myc and c-myc expres- 
sion in normal precursor B lymphocytes. Genes \& Dev. 6: 61-70.

Papoulas, O., N.G. Williams, and R.E. Dingston. 1992. DNA binding activities of c-myc purified from eukaryotic cells. $J$. Biol. Chem. 267: 10470-10480.

Prendergast, G.C. and E.B. Ziff. 1992. A new bind for myc. Trends Genet. 8: 91-96.

Prendergast, G.C., L.E. Diamond, D. Dhal, and M.D. Cole. 1990. The c-myc regulated gene $\mathrm{mr}$ encodes plasminogen activator inhibitor 1. Mol. Cell. Biol. 10: 1265-1269.

Prochownik, E.V., J. Kukowska, and C. Rodgers. 1988. c-myc antisense transcripts accelerate differentiation and inhibit Gl progression in murine erythroleukemia cells. Mol. Cell. Biol. 8: 3683-3695.

Robertson, E.J., ed. 1987. Embryo-derived stem cell lines. In Teratocarcinomas and embryonic stem cells: A practical approach, pp. 71-112. IRL Press, Oxford, England.

Roussel, M.F., J.L. Cleveland, S.A. Shurtleff, and C.J. Sherr. 1991. Myc rescue of a mutant CSF-1 receptor impaired in mitogenic signalling. Nature 353: 361-363.

Sejersen, T., H. Bjorklund, J. Sumegi, and N.R. Ringertz. 1986. $\mathrm{N}$-myc and c-src genes are differentially regulated in PCC7 embryonal carcinoma cells undergoing neuronal differentiation. J. Cell. Physiol. 127: 274-280.

Sejersen, T., M. Rahm, G. Szabo, S. Ingvarsson, and J. Sumegi. 1987. Similarities and differences in the regulation of N-myc and c-myc genes in murine embryonal carcinoma cells. Exp. Cell Res. 172: 304-317.

Soriano, P., C. Montgomery, R. Geske, and A. Bradley. 1991. Targeted disruption of the c-src protocogene leads to osteopetrosis in mice. Cell 64: 693-702.

Southern, E.M. 1975. Detection of specific sequences among DNA fragments separated by gel electrophoresis. $/$. Mol. Biol. 98: 503-517.

Spencer, C.A. and M. Groudine. 1991. Control of c-myc regulation in normal and neoplastic cells. Adv. Cancer Res. 56: $1-48$.

Spotts, G.D. and S.R. Hann. 1990. Enhanced translation and increased turnover of c-myc proteins occur during differentiation of murine erythroleukemia cells. Mol. Cell. Biol. 10: $3952-3964$.

Stanton, B.R., A.S. Perkins, L. Tessarollo, D.A. Sassoon, and L.F. Parada. 1992. Loss of N-myc function results in embryonic lethality and failure of the epithelial component of the embryos to develop. Genes \& Dev. 6: 2235-2247.

Swain, J.L., T.A. Stewart, and P. Leder. 1987. Parental legacy determines methylation and expression of an autosomal transgene: A molecular mechanism for parental imprinting. Cell 50: 719-727.

Taira, T., Y. Negishi, J. Kihara, S.M.M. Iguchi-Ariga, and H. Ariga. 1992. C-myc protein complex binds to two sites in human hsp70 promoter region. Biochim. Biophys. Acta 1130: $166-174$

Te Riele, H., E.R. Maandag, A. Clarke, M. Hooper, and A. Berns. 1990. Consecutive inactivation of both alleles of the pim-1 proto-oncogene by homologous recombination in embryonic stem cells. Nature 348: 649-651.

van Lohuizen, M., S. Verbeek, B. Scheijen, E. Wientjens, H. van der Gulden, and A. Berns. 1991. Identification of cooperating oncogenes in Emu-myc transgenic mice by provirus tagging. Cell 65: $737-752$.

Whitman, M.M., Y.K. Shen, D. Soprano, and K.J. Soprano. 1990. Molecular analysis of early growth-associated events during the differentiation of F9 cells into embryoid bodies. Cancer Res. 50: 3193-3198.

Wickstrom, E.L., T.A. Bacon, A. Gonzalez, D.L. Freeman, G.H.
Lyman, and E. Wickstrom. 1988. Human promyelocytic leukemia HL-60 cell proliferation and c-myc protein expression are inhibited by an antisense pentadecadeoxynucleotide targeted against c-myc mRNA. Proc. Natl. Acad. Sci. 85: 10281032 . 


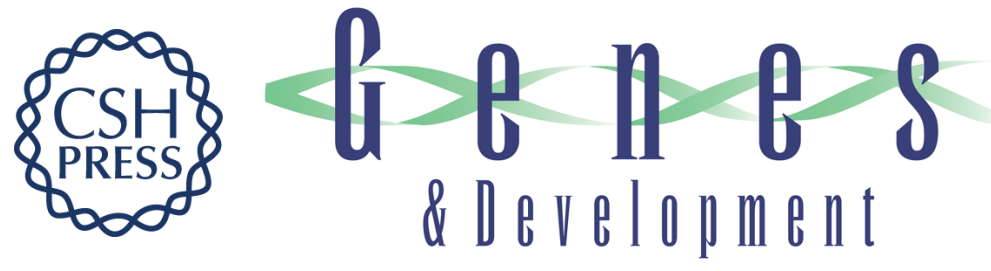

\section{A null c-myc mutation causes lethality before 10.5 days of gestation in homozygotes and reduced fertility in heterozygous female mice.}

A C Davis, M Wims, G D Spotts, et al.

Genes Dev. 1993, 7:

Access the most recent version at doi:10.1101/gad.7.4.671

References This article cites 50 articles, 17 of which can be accessed free at:

http://genesdev.cshlp.org/content/7/4/671.full.html\#ref-list-1

License

Email Alerting

Service

Receive free email alerts when new articles cite this article - sign up in the box at the top right corner of the article or click here.

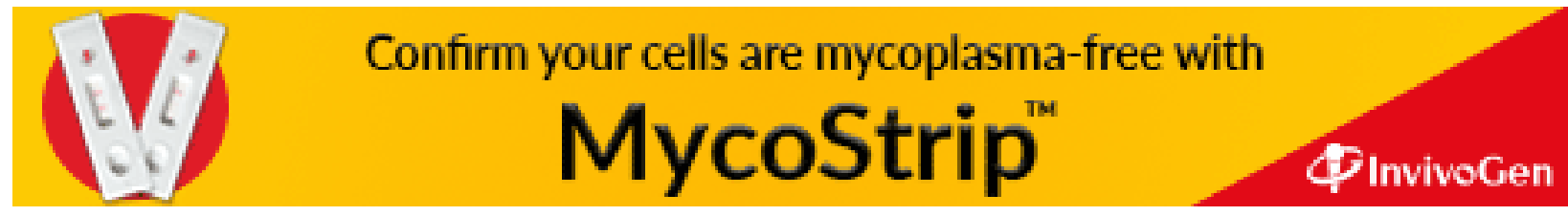

